\title{
Status of the 3D Elevation Program, 2015
}

Open-File Report 2016-1196 



\section{Status of the 3D Elevation Program, 2015}

By Larry J. Sugarbaker, Diane F. Eldridge, Allyson L. Jason, Vicki Lukas,

David L. Saghy, Jason M. Stoker, and Diana R. Thunen

Open-File Report 2016-1196

U.S. Department of the Interior

U.S. Geological Survey 


\section{U.S. Department of the Interior SALLY JEWELL, Secretary}

\section{U.S. Geological Survey Suzette M. Kimball, Director}

\section{U.S. Geological Survey, Reston, Virginia: 2017}

For more information on the USGS - the Federal source for science about the Earth, its natural and living resources, natural hazards, and the environment—visit http://www.usgs.gov or call 1-888-ASK-USGS.

For an overview of USGS information products, including maps, imagery, and publications, visit http://www.usgs.gov/pubprod/.

Any use of trade, firm, or product names is for descriptive purposes only and does not imply endorsement by the U.S. Government.

Although this information product, for the most part, is in the public domain, it also may contain copyrighted materials as noted in the text. Permission to reproduce copyrighted items must be secured from the copyright owner.

Suggested citation:

Sugarbaker, L.J., Eldridge, D.F., Jason, A.L., Lukas, Vicki, Saghy, D.L., Stoker, J.M., and Thunen, D.R., 2017, Status of the 3D Elevation Program, 2015: U.S. Geological Survey Open-File Report 2016-1196, 13 p., https://doi.org/10.3133/ ofr20161196. 


\section{Acknowledgments}

The 3D Elevation Program (3DEP) initiative is a partnership among many individuals within the U.S. Geological Survey (USGS) and across our partner Federal, State, and professional organizations. The authors wish to acknowledge the 3DEP Executive Forum and Working Group members for their guidance, expertise, and enthusiastic collaboration on our mutual goal of nationwide 3D elevation coverage. Members of the Executive Forum represent several organizations and agencies: Doug Bellomo (Federal Emergency Management Agency [FEMA]), Juliana Blackwell (National Oceanic and Atmospheric Administration [NOAA]), Emilee Blount (U.S. Forest Service [USFS]), Thadd Buzan (Office of Secretary of Defense), Thomas Dabolt (Department of the Interior [DOI]), John Dennis (National Park Service [NPS]), Jennifer Gimbel (DOI), Darren Hickman (Natural Resources Conservation Service [NRCS]), Paul Huang (Department of Homeland Security [DHS]), Jerry Johnston (DOI), Charles Kershner (National Geospatial-Intelligence Agency [NGA]), David LaBranche (Office of Secretary of Defense), Joe Mullins (Army Geospatial Center [AGC]), Aaron Ray (Office of Management and Budget [OMB]), Luis Rodriguez (FEMA), Ray Sauvajot (NPS), David Smith (U.S. Department of Agriculture [USDA]), Timothy Stryker (Office of Science and Technology Policy [OSTP]), Camille Touton (DOI), and Seshu Vaddey (NPS). Members of the Working Group also represent several organizations and agencies: Nancy Blyler (U.S. Army Corps of Engineers [USACE]), Matthew Bobo (Bureau of Land Management [BLM]), Ashley Chappell (NOAA), Dwain Daniels (NRCS), David Duran (NPS), Kenneth Elsner (U.S. Fish and Wildlife Service [USFWS]), David Finnegan (USACE), Brian Hadley (BLM), Everett Hinkley (U.S. Forest Service [USFS]), Darcee Killpack (NPS), Collin McCormick (NRCS), Steven Nechero (NRCS), Doug Newcomb (USFWS), William Nye (USACE), Jay Parrish (Association of American State Geologists [AASG]), Kamiliah Pendleton (Office of Surface Mining Reclamation and Enforcement [OSMRE]), Sasha Pryborowski (NOAA), Paul Rooney (FEMA), Craig Seaver (Environmental Protection Agency [EPA]), Harvey Thorliefson (AASG), Brian Vanderbilt (USDA), Kirk Waters (NOAA), and Phil Worrall (National States Geographic Information Council [NSGIC]). The authors wish to acknowledge our many external partners and collaborators for their participation and support of 3DEP. We thank also Suzette Kimball, USGS Director, and Kevin Gallagher, USGS Associate Director for Core Science Systems, for their ongoing commitment and leadership to make 3DEP a success. 


\section{Contents}

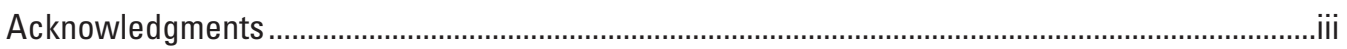

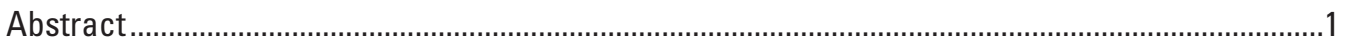

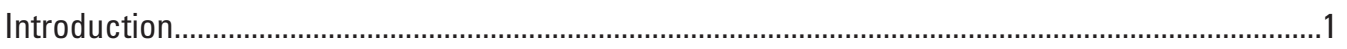

U.S. Interagency Elevation Inventory Results for Fiscal Year 2015 ...............................................

3D Elevation Program Data Collection Contracted in Fiscal Year 2015 ...........................................5

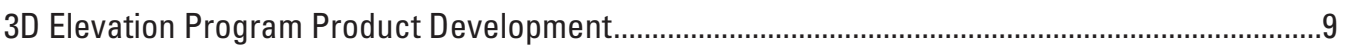

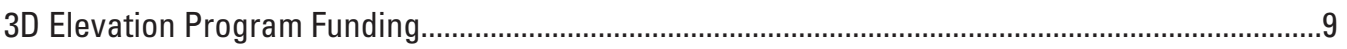

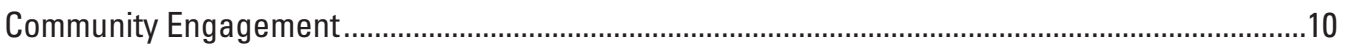

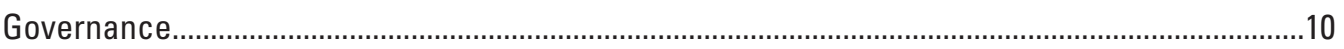

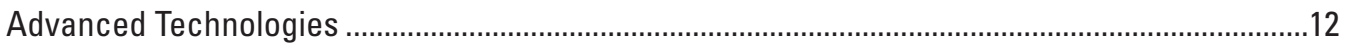

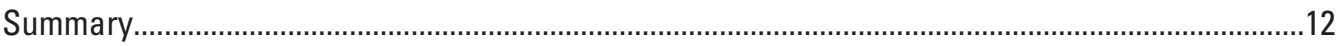

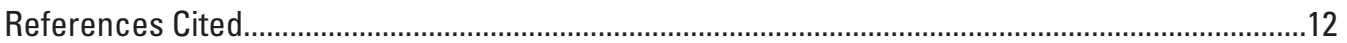

\section{Sidebars}

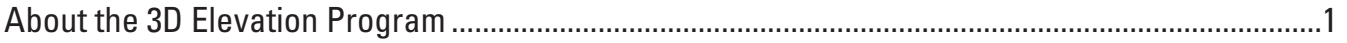

Light Detection and Ranging Data and Bird Nesting in North Carolina ............................................

Light Detection and Ranging Data and the National Hydrography Dataset ......................................

Light Detection and Ranging Data for Earthquake Hazards Mapping ............................................11

\section{Figures}

1. Map showing areal coverage of light detection and ranging elevation data collected in the United States and U.S. territories before and in fiscal year 2015 that meet 3D Elevation Program base-level specifications (Quality Level 2)...

2. Graph showing total light detection and ranging data per quality level acquired by fiscal year, 2007-15.

3. Map showing publicly available interferometric synthetic aperture radar data collected in Alaska before and in fiscal year 2015 that meet 3D Elevation Program base-level specifications (Quality Level 5)

4. Map depicting the areas covered by 3D Elevation Program acquisition awards for new light detection and ranging and interferometric synthetic aperture radar data acquisition projects planned for fiscal year 2015 and that meet 3D Elevation Program base-specifications in the United States and U.S. territories.

5. Graph showing new light detection and ranging point cloud data available (2013-15) and projected (2016) for download by fiscal year and quality level

6. Chart showing fiscal year 2015 3D Elevation Program data acquisition funding and gap to reach annual investment needed for the 8-year program, assuming level investment in each year

7. Graph showing U.S. Geological Survey 3D Elevation Program scenarios to fund one-third of data acquisition and to fully fund related quality assurance and quality control, processing, data management, and product delivery

8. Diagram showing the 3D Elevation Program governance structure 


\section{Tables}

1. Total acquisition area covered by contracts awarded by fiscal year (2013-15) including U.S. Geological Survey and partner organization contracts for light detection and ranging data (all quality levels) in the United States and U.S. territories and interferometric synthetic aperture radar data in Alaska ....................7

2. Amount of light detection and ranging data for the U.S. and territories, and interferometric synthetic aperture radar data within Alaska placed under contract by fiscal year (2013-15)

3. Comparison of average acquisition costs of light detection and ranging data and interferometric synthetic aperture radar data, presented by 3D Elevation Program quality level for the fiscal years 2012-15. 



\title{
Status of the 3D Elevation Program, 2015
}

\author{
By Larry J. Sugarbaker, Diane F. Eldridge, Allyson L. Jason, Vicki Lukas, David L. Saghy, \\ Jason M. Stoker, and Diana R. Thunen
}

\begin{abstract}
The 3D Elevation Program (3DEP) is a cooperative activity to collect light detection and ranging (lidar) data for the conterminous United States, Hawaii, and U.S. territories; and interferometric synthetic aperture radar (IfSAR) elevation data for Alaska during an 8-year period. The U.S. Geological Survey (USGS) and partner organizations acquire high-quality three-dimensional elevation data for the United States and its territories that support requirements beyond what could be realized if agencies independently pursued lidar and IfSAR data collection activities. Data collection rates have been increasing as a growing number of State and Federal agencies participate in cooperative data acquisition projects. USGS and partner agencies expanded data collection, completed the initial product delivery systems and implemented changes to the program governance to include a restructuring of the 3DEP working group and formalizing the relationship to the Federal Geographic Data Committee during the final year (2015) of program preparation.
\end{abstract}

\section{Introduction}

The 3D Elevation Program (3DEP) is a major cooperative activity (sidebar, p. 1-2) to collect light detection and ranging (lidar) data for the conterminous United States, Hawaii, and U.S. territories; and interferometric synthetic aperture radar (IfSAR) data for Alaska. The U.S. Geological Survey (USGS) and partner organizations acquire high-quality threedimensional (3D) elevation data for the United States and its territories that support requirements beyond what could be realized if agencies independently pursued lidar and IfSAR data collection activities (Sugarbaker, 2014; U.S. Geological Survey, 2014b). 3DEP data are already being used for a range of innovative applications (sidebars, p. 4, 8, 11).

The primary activities during 2012 through 2015 were program growth, new data collection, product and service development, and technology modernization (Lukas, 2015). Data collection rates have been increasing as a growing number of State and Federal agencies participate in cooperative data acquisition projects. During 2015, the final year of program preparation, projects focused on the expansion of

\section{About the 3D Elevation Program}

The 3D Elevation Program (3DEP) is a national program managed by the U.S. Geological Survey (USGS) to acquire high-resolution elevation data (Sugarbaker, 2014). It produces point clouds, bare-earth digital elevation models (DEMs), and other products.

The 3DEP is backed by a comprehensive assessment of light detection and ranging (lidar), interferometric synthetic aperture radar (IfSAR), and related elevation data requirements (Dewberry, 2012) and is now an operational program. The goal of this high-priority cooperative program is to have complete coverage of Quality Level 2 (QL2) lidar data for the conterminous United States, Hawaii, and U.S. territories; and IfSAR data for Alaska by the end of 2023.

\section{Reduced Acquisition Costs and Risks}

A funded national program will provide the following:

- Economy of scale by acquiring data for larger areas and reducing acquisition costs by 25 percent.

- Predictable, efficient, and flexible Federal investments that reduce costs for and allow better planning by Federal, State, Tribal, U.S. territories, and local government partners, including the option of "buying up" to acquire higher quality data.

- Consistent, high-quality data and national coverage that provide data ready for applications that span project, jurisdictional, and watershed boundaries; meet multiple needs; and increase benefits to citizens.

- Simpler data acquisition that provides contracts, published data acquisition specifications, and specialized quality assurance and information technology expertise. Partners reduce their risks and concentrate on their business activities.

The 3DEP can conservatively provide new benefits of $\$ 690$ million per year and has the potential to generate $\$ 13$ billion per year in new benefits through applications that span the economy (Dewberry, 2012). The shared lidar, IfSAR, and derived elevation datasets would foster cooperation and improve decision making among all levels of government and other stakeholders. 


\section{About the 3D Elevation Program-Continued}

\author{
High-Quality Data
}

For the conterminous United States, Hawaii, and the U.S. territories, the USGS and its partners acquire QL2 or better aerial lidar data. The QL2 data have a minimum nominal pulse spacing of 0.7 meters and a vertical error of 10 centimeters, measured as root mean square error in the elevation $(z)$ dimension (RMSE). Statewide for Alaska, QL5 IfSAR data are acquired that have a vertical error of 185 centimeters RMSE .

The data must have been acquired during the previous 8 years. For more information, see the Lidar Base Specification available at http://pubs.usgs.gov/tm/11b4/.

\section{Point Cloud and Derived Products}

Lidar data products include the all-return classified point clouds and derived bare-earth DEMs. Each DEM dataset is identified by its horizontal resolution and is produced to a consistent set of specifications. All DEMs represent the topographic surface of the Earth and contain flattened water surfaces. Nationally seamless DEMs are produced by blending only the highest quality project data into a continuous terrain surface for the United States and are published at $1 / 3$ arc-second, 1 arc-second, and 2 arc-second resolutions. The standard 1-meter DEM dataset is seamless within collection projects but not across projects.

The IfSAR data in Alaska include digital surface models, orthorectified intensity images, and 5-meter resolution hydro-flattened DEMs.

The USGS integrates the elevation model data into its national elevation data coverage, as a component of The National Map. All 3DEP products to include an elevation point query service and bulk point query service are components of The National Map. Data are available, free of charge and without use restrictions. To download 3DEP products visit: http://viewer.nationalmap.gov/basic/.

\section{Ways to Participate}

Partners may contribute funds toward data acquisition projects managed by the USGS, or they may receive cooperative funds to manage their own acquisition projects. The broad agency announcement process is the primary mechanism used to establish agreements between partners. For more information see the 3DEP Web site at http://nationalmap.gov/3DEP/index.html. Organizations may also access the geospatial products and services contracts and qualitycontrol services managed by USGS to acquire 3DEP data. Organizations may contribute existing elevation data that meets 3DEP specifications. More information about using USGS contracts or other ways to contribute is available by request through http://nationalmap.gov/3DEP/3dep_feedback.html. data collection activities and initiation of product delivery services. The combined efforts of a broad partnership community are achieving the envisioned 3DEP goal. In particular, partners are pooling funds to collect lidar data over larger areas and at lower costs than achieved in 2012 to 2014. This annual report highlights the progress that has been made in the past year to implement 3DEP.

\section{U.S. Interagency Elevation Inventory Results for Fiscal Year 2015}

The USGS and the National Oceanic and Atmospheric Administration (NOAA) maintain the U.S. Interagency Elevation Inventory (USIEI; https://coast.noaa.gov/inventory/) of all publicly available lidar and IfSAR data to guide new data acquisition and avoid duplication. The fiscal year 2015 (FY15) update of the USIEI indicates that 113,896 square miles $\left(\mathrm{mi}^{2}\right)$ of new Quality Level 2 (QL2) or better lidar data were acquired in FY15 by Federal, State, and other organizations covering 3.8 percent of 49 States (not including Alaska) and the U.S. territories. The areas where lidar were collected that meet the QL2 requirements of 3DEP are shown in figure 1. The USIEI includes public sources of lidar in all States that meet 3DEP specifications (FY08-FY15). Information is provided by users during the annual USIEI survey and was updated in October 2015. The USIEI also includes lidar point cloud data that are in production and unpublished as of the report release date. The availability from State and Federal agencies is available on the USIEI Web site at https://coast. noaa.gov/inventory/. The latest reports and maps for all USGS published lidar point cloud data are available at http://nationalmap.gov/3DEP/3dep_prodavailability.html.

Data collections by FY (2007-15) for QL2 and better quality lidar are shown in figure 2. The collection of QL2 or better lidar data continues to increase substantially, whereas the collection of QL3 and lower quality lidar continues to decline. In FY15, the inventory reported that $20,517 \mathrm{mi}^{2}$ of QL3 and lower quality lidar were collected, a decrease from $54,414 \mathrm{mi}^{2}$ in FY14. The trend toward QL2 or better data is expected to continue as users realize greater utility in the higher quality data and acquisition costs decline (see the "3D Elevation Program Data Collection Contracted in Fiscal Year 2015 " section). To accomplish the program goal to collect lidar in 49 U.S. States and U.S. territories and IfSAR data in Alaska in 8 years, 12.5 percent of QL2 or better lidar data (QL5 IfSAR data in Alaska) would need to be collected each year.

Owing to the frequently unfavorable weather and remote conditions, IfSAR is the technology best suited for statewide data collection in Alaska. IfSAR data were collected in Alaska for $69,444 \mathrm{mi}^{2}$ covering 12 percent of the State in FY15. The IfSAR coverage area in Alaska is shown in figure 3. 


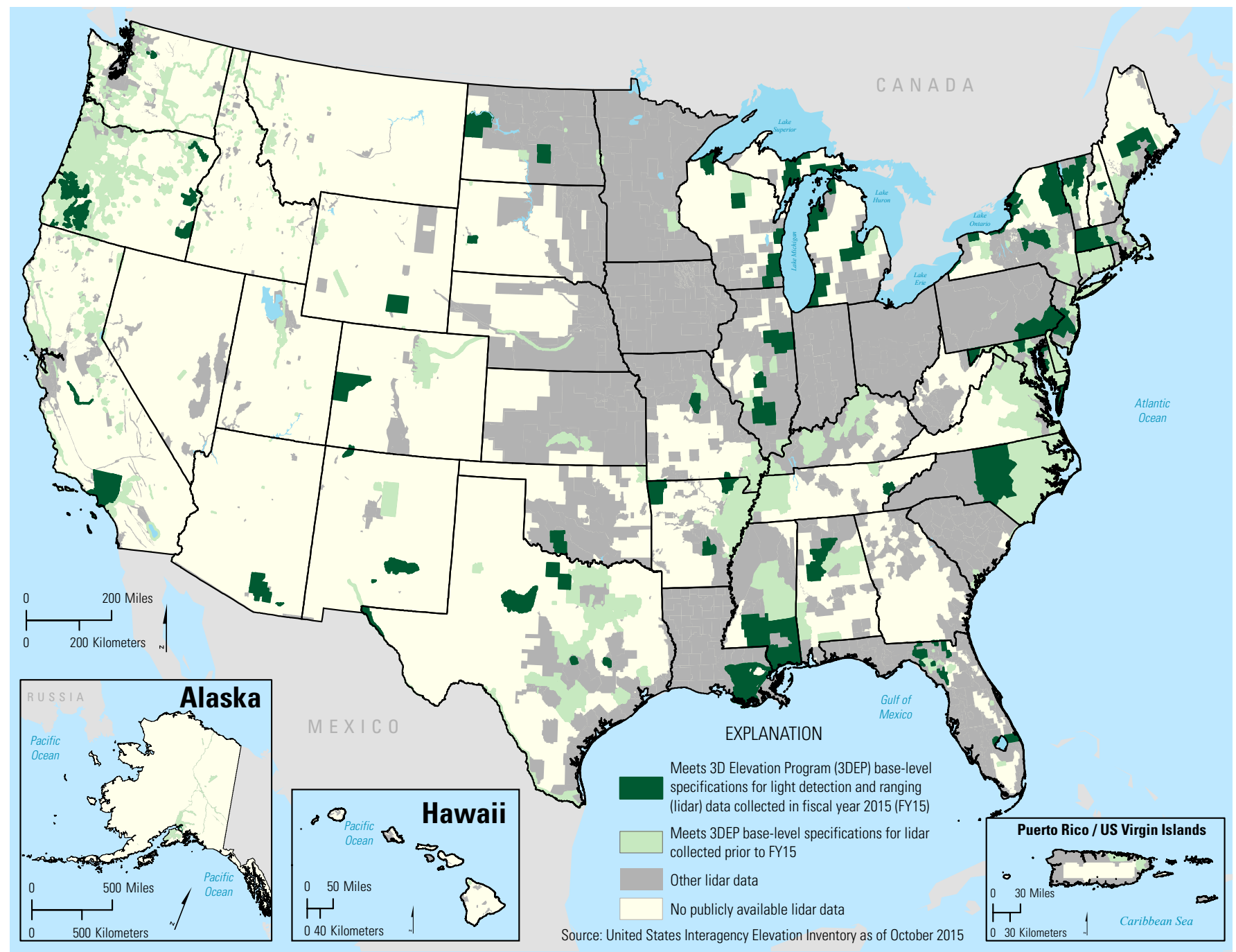

Figure 1. Map showing areal coverage of light detection and ranging elevation data collected in the United States and U.S. territories before and in fiscal year 2015 that meet 3D Elevation Program base-level specifications (Quality Level 2).

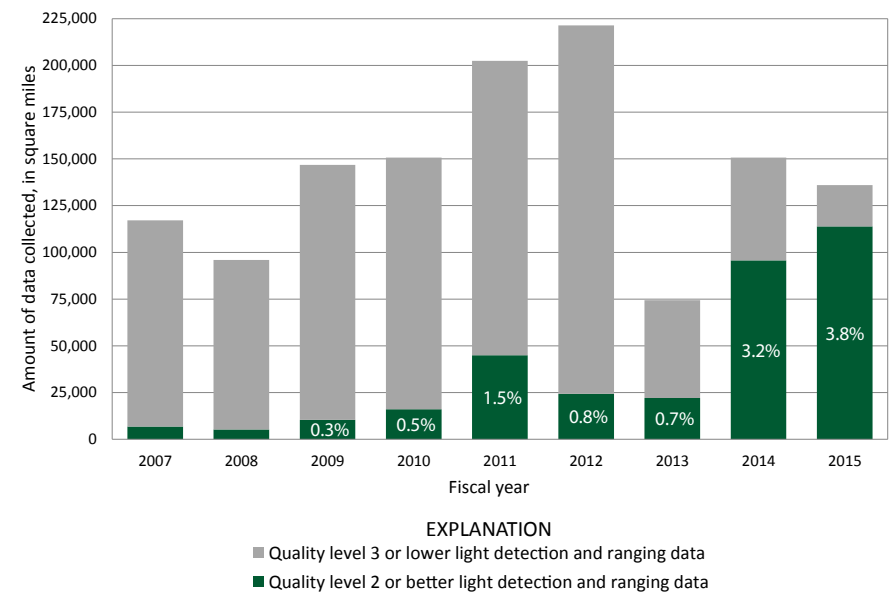

Figure 2. Graph showing total light detection and ranging data per quality level acquired by fiscal year, 2007-15. Source: U.S. Interagency Elevation Inventory (USIEI).

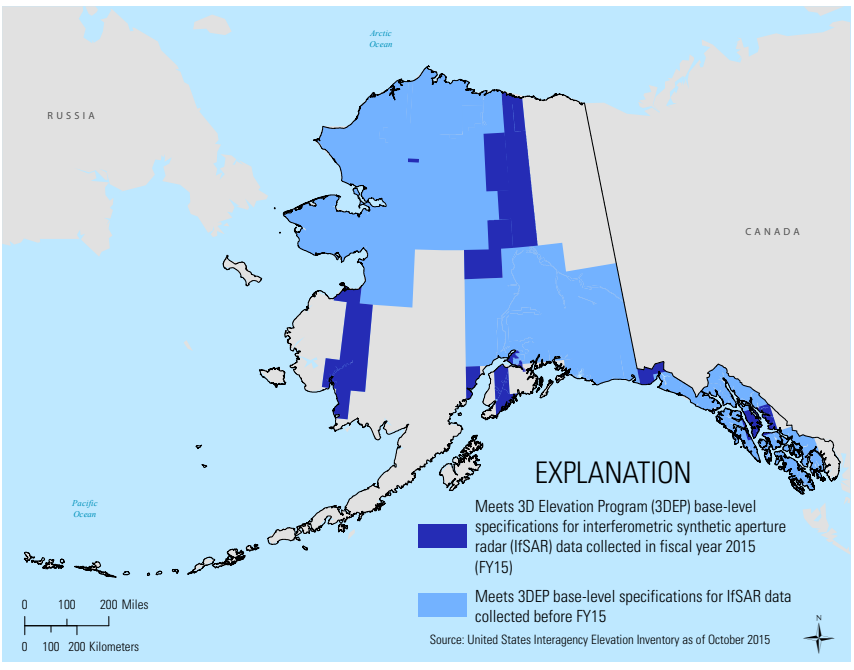

Figure 3. Map showing publicly available interferometric synthetic aperture radar data collected in Alaska before and in fiscal year 2015 that meet 3D Elevation Program base-level specifications (Quality Level 5). 


\section{Light Detection and Ranging Data and Bird Nesting in North Carolina}

Light detection and ranging (lidar) project —-North Carolina Statewide lidar phase 1

Collection year-2014

Quality level (QL) - QL2

State-North Carolina

Product author-Doug Newcomb, U.S. Fish and Wildlife Service, Raleigh, North Carolina

Description - The State of North Carolina was able to leverage Hurricane Sandy Recovery funding from the U.S. Geological Survey and U.S. Department of Agriculture to obtain QL2 (0.7-meter posting distance, 9-centimeter vertical accuracy) lidar data for 19 counties on the North Carolina coast. North Carolina funded the collection of QL2 lidar data for an additional 21 coastal counties in North Carolina at the same time. The data were analyzed to create seamless raster datasets for canopy height, lidar height variance, lidar point count, and lidar height skewness at 60x60 and 20x20 feet cell sizes over the 40-county area. Although the effort is still underway, initial results indicate a correlation between known bird nesting locations and tree canopy height as modeled from the lidar data.
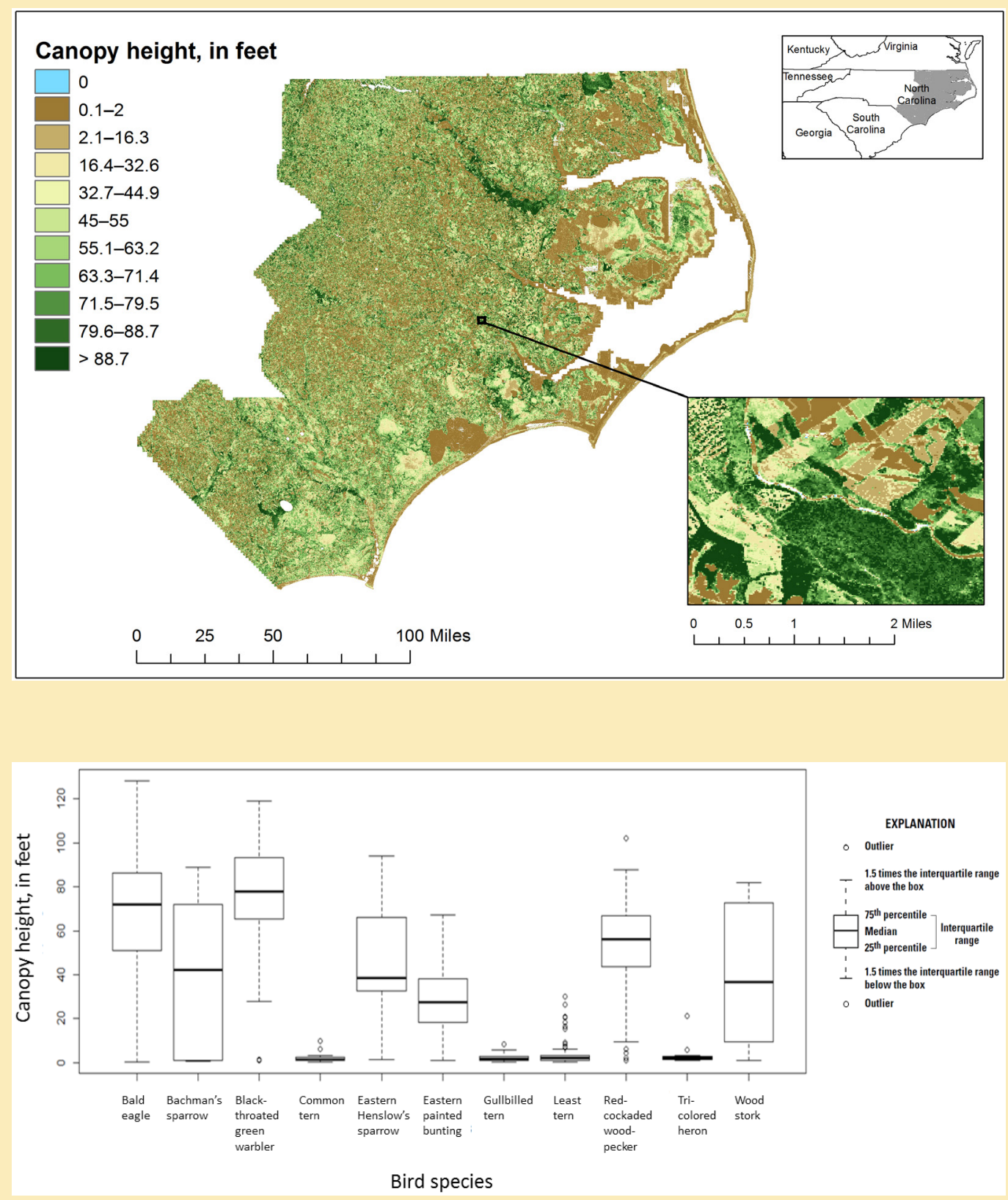

Map showing canopy height was created from the 2014 North Carolina light detection and ranging dataset. Source: Doug Newcomb, U.S. Fish and Wildlife Service, Raleigh, North Carolina.
Graph showing mean values of canopy height within a 25-meter buffer area around bird species nesting locations as derived from the North Carolina Natural Heritage Program dataset. Source: Doug Newcomb, U.S. Fish and Wildlife Service, Raleigh, North Carolina. 


\section{D Elevation Program Data Collection Contracted in Fiscal Year 2015}

In FY15, the lidar mapping of over $150,000 \mathrm{mi}^{2}$ was scheduled for collection through a variety of contracts and partnerships. These data were collected in FY15 and FY16. The Broad Agency Announcement (BAA) is the public process used by the USGS to select and define lidar acquisition partnerships. These awards can be granted to partners who will oversee the acquisition of data, or they may be managed by the USGS through the Geospatial Products and Services Contracts (GPSC). In addition to the BAA process, partners may use the GPSC directly to acquire data, or they may contribute data acquired through other means that meet the minimum QL2 specifications. The GPSC include quality and content specifications (American Society for Photogrammetry and Remote Sensing, 2012; American Society for Photogrammetry and Remote Sensing, 2014; Heidemann, 2014); moreover, the GPSC is the preferred 3DEP acquisition vehicle because the contractors acquiring data under this vehicle must meet strict performance requirements, ultimately leading to program cost efficiencies and a more consistent product. The BAA resulted in 29 projects in 26 States and U.S. territories in FY15. Where requirements could not be addressed through the BAA process, additional Federal acquisitions were made through GPSC and are included in the overall FY15 data collection contracting total (fig. 4).

There are several notable trends that are happening among 3DEP GPSC and partner contracts. The total investment in data collection among all partners continues to increase. In FY13, USGS and partner investments in 3DEP totaled about \$24 million, and in FY15 they increased substantially to about $\$ 46$ million (table 1). Although the increased investments mean greater lidar coverage, the overall quality level of data collected has shifted as well. In FY15 no QL3 contracts were awarded through the BAA process, a trend which is being mirrored throughout the industry. In FY13, 49,000 $\mathrm{mi}^{2}$ of QL1-QL2 lidar data collection contracts were awarded (table 2). In FY15, that number increased to $150,000 \mathrm{mi}^{2}$ of QL1-QL2 lidar data (table 2). Investments in IfSAR data, part of the Alaska Mapping Initiative, have remained stable at about $\$ 7$ million per year (table 1). The funding mix for USGS and other partners include both annual appropriations and other funds. For example, USGS received a supplemental appropriation for lidar to respond to Hurricane Sandy recovery efforts in FY13 and FY14. Partner funds are defined as partner financial contributions for data acquisition through cooperative agreements and GPSC task orders. In addition, some data were contributed to USGS and are being made available for download. These contributed datasets are not included in the summarized investment information (table 1).

The USGS monitors data collection costs and evaluates the average cost per square mile for representative projects each year (table 3 ). In the past, this has been reported as the total acquisition cost consisting of collection contracts, quality assurance and quality control (QA/QC), and contract administration (Lukas, 2015). Beginning in FY15, the USGS is no longer including QA/QC and contract administration as part of the data collection per square mile cost analysis. The $\mathrm{QA} / \mathrm{QC}$ and contract administration costs are now included in the program operations budget. This change was made to be consistent with Federal and State partner reporting of data collection cost. The FY15 QL2 data collection cost was based on an evaluation of 47 USGS and partner data collection contracts. Lidar projects with unusual costs or missing cost components were not included in the analysis nor were projects in Hawaii, Puerto Rico, and the U.S. Trust Territories, which are highly variable because of high costs of aircraft mobilization, weather, and other factors related to operating in remote locations. The costs identified can be used as a baseline for developing project estimates; however, care should be exercised when using the average cost figures for data-collection cost estimates in remote locations or for areas having difficult terrain.

The lidar data collection costs continue to decline. The average cost per square mile for QL2 lidar in FY13 was \$289 and the average project size was $1,665 \mathrm{mi}^{2}$. The average cost per square mile in FY15 was $\$ 226$, and the average project size was $2,836 \mathrm{mi}^{2}$. Increasing project size is a specific objective of $3 \mathrm{DEP}$ and is one of the criteria used when making awards through the BAA process. Larger projects produce consistent data across large areas and lower program management costs. The IfSAR data collection costs have increased in Alaska primarily because of the remoteness and rugged terrain associated with the remaining collection cells. 


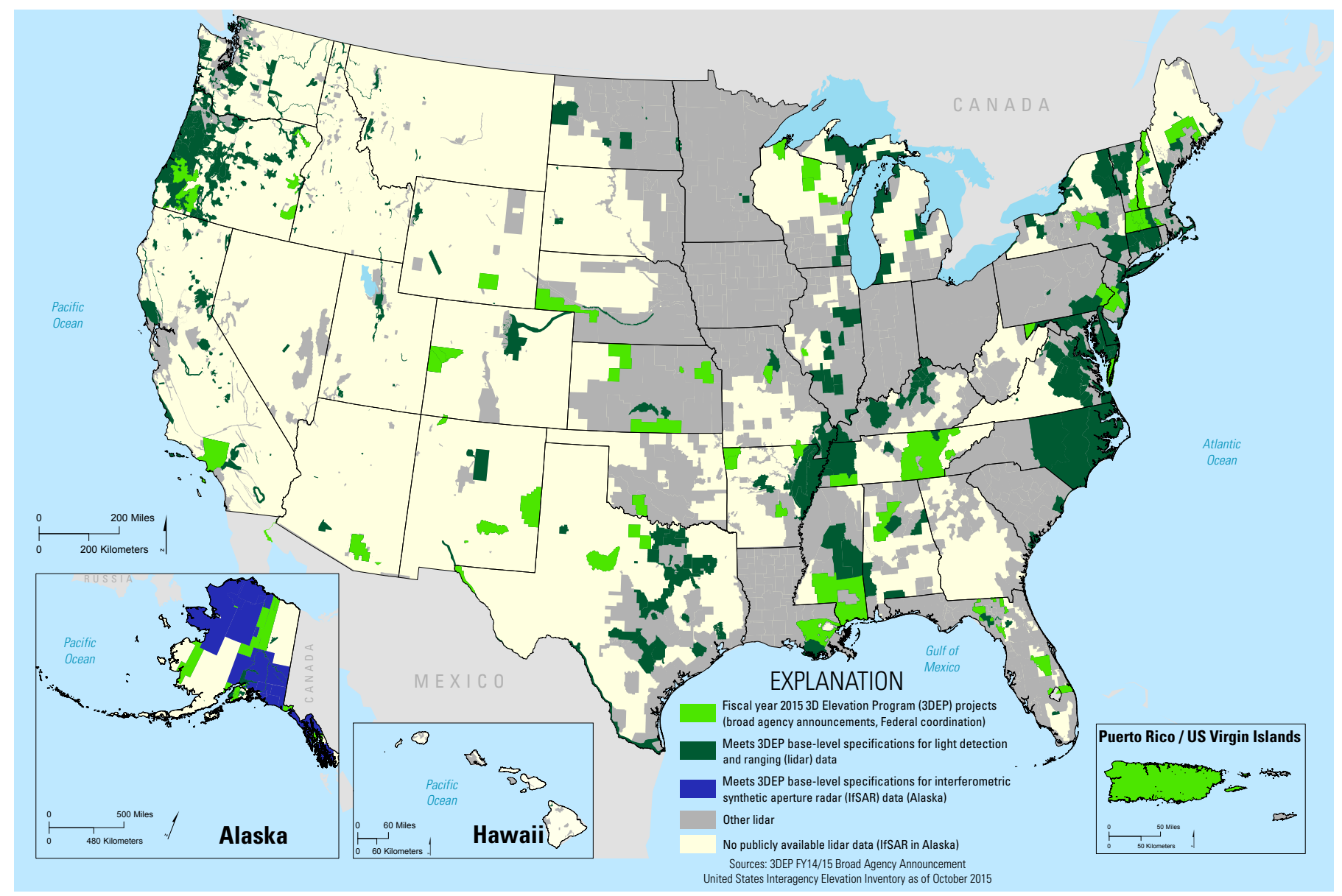

Figure 4. Map depicting the areas covered by $3 D$ Elevation Program acquisition awards for new light detection and ranging and interferometric synthetic aperture radar data acquisition projects planned for fiscal year 2015 and that meet 3D Elevation Program basespecifications in the United States and U.S. territories. 
Table 1. Total acquisition area covered by contracts awarded by fiscal year (2013-15) including U.S. Geological Survey and partner organization contracts for light detection and ranging data (all quality levels) in the United States and U.S. territories and interferometric synthetic aperture radar data in Alaska.

[FY, fiscal year; USGS, U.S. Geological Survey; FEMA, Federal Emergency Management Agency; NRCS, Natural Resources Conservation Service; lidar, light detection and ranging; QL, quality level; IfSAR, interferometric synthetic aperture radar]

\begin{tabular}{|c|c|c|c|c|c|c|c|c|c|c|c|}
\hline & \multicolumn{3}{|c|}{$\begin{array}{c}\text { FY13 contracts, } \\
\text { in millions of dollars }\end{array}$} & \multicolumn{3}{|c|}{$\begin{array}{c}\text { FY14 contracts, } \\
\text { in millions of dollars }\end{array}$} & \multicolumn{5}{|c|}{$\begin{array}{c}\text { FY15 contracts, } \\
\text { in millions of dollars }\end{array}$} \\
\hline & USGS & Partners & Total & USGS & Partners & Total & USGS & FEMA & NRCS & $\begin{array}{l}\text { Other } \\
\text { partners }\end{array}$ & Total \\
\hline Lidar QL1-2 & 4.04 & 9.34 & 13.38 & 7.31 & 20.53 & 27.84 & 7.16 & 11.24 & 7.08 & 13.50 & 38.98 \\
\hline Lidar QL3 & 0.56 & 2.80 & 3.36 & 0.70 & 5.48 & 6.18 & 0.00 & 0.00 & 0.00 & 0.00 & 0.00 \\
\hline $\begin{array}{l}\text { IfSAR } \\
\text { (Alaska) }\end{array}$ & 3.54 & 3.24 & 6.78 & 2.84 & 4.07 & 6.91 & 3.61 & 0.00 & 0.07 & 3.68 & 7.36 \\
\hline TOTAL & 8.14 & 15.38 & 23.52 & 10.85 & 30.08 & 40.93 & 10.77 & 11.24 & 7.15 & 17.18 & 46.34 \\
\hline
\end{tabular}

Table 2. Amount of light detection and ranging data for the U.S. and territories, and interferometric synthetic aperture radar data within Alaska placed under contract by fiscal year (2013-15).

[FY, fiscal year; lidar, light detection and ranging; QL, quality level; IfSAR, interferometric synthetic aperture radar]

\begin{tabular}{lcccc}
\hline & $\begin{array}{c}\text { FY13 } \\
\text { square miles }\end{array}$ & $\begin{array}{c}\text { FY14 } \\
\text { square miles }\end{array}$ & $\begin{array}{c}\text { FY15 } \\
\text { square miles }\end{array}$ & $\begin{array}{c}\text { FY13-FY15 } \\
\text { total square miles }\end{array}$ \\
\hline Lidar QL1-2 & 49,000 & 80,000 & 150,000 & 279,000 \\
Lidar QL3 & 24,000 & 25,000 & 0 & 49,000 \\
IfSAR (Alaska) & 69,000 & 80,000 & 69,000 & 218,000 \\
\hline
\end{tabular}

Table 3. Comparison of average acquisition costs of light detection and ranging data and interferometric synthetic aperture radar data, presented by 3D Elevation Program quality level for the fiscal years 2012-15.

[QL, quality level; lidar, light detection and ranging; IfSAR, interferometric synthetic aperture radar]

\begin{tabular}{lllll}
\hline \multirow{2}{*}{ Quality level' } & \multicolumn{4}{c}{$\begin{array}{c}\text { Average cost per square mile } \\
\text { (number of projects evaluated; average size of project in square miles) }\end{array}$} \\
\cline { 2 - 5 } & \multicolumn{1}{c}{$\mathbf{2 0 1 2}$} & $\mathbf{2 0 1 3}$ & $\mathbf{2 0 1 4}$ & \multicolumn{1}{c}{$\mathbf{2 0 1 5}$} \\
\hline QL1 lidar & $\$ 698(1 ; 2,021)$ & $\$ 520(6 ; 934)$ & $\$ 680(7 ; 1,009)$ & $\$ 478(6 ; 1,429)$ \\
QL2 lidar & $\$ 378(3 ; 648)$ & $\$ 289(20 ; 1,665)$ & $\$ 284(23 ; 2,504)$ & $\$ 226(47 ; 2,836)$ \\
QL3 lidar & $\$ 228(28 ; 2,183)$ & $\$ 142(9 ; 2,632)$ & $\$ 220(4 ; 6,225)$ & N/A \\
QL5 IfSAR & $\$ 95$ & $\$ 100$ & $\$ 110$ & $\$ 127$ \\
\hline
\end{tabular}

${ }^{1}$ For definitions of quality levels, refer to the lidar base specification (Heidemann, 2014).

${ }^{2}$ Numbers within parentheses next to lidar cost information are representative projects flown and average project size in square miles for Geospatial Products and Services Contracts (GPSC) and partner projects. 


\section{Light Detection and Ranging Data and the National Hydrography Dataset}

\author{
Light detection and ranging (lidar) project - Central \\ Mississippi \\ Collection year-2014
}

Quality level (QL) - QL2, 1-meter digital elevation model (DEM)

State-Mississippi

Product author-Barbara Yassin, Mississippi Department of Environmental Quality_Office of Geology

Description - Lidar is used to create the 1:4,800 LocalResolution National Hydrography Dataset from 1-meter DEMs generated from U.S. Geological Survey, Natural Resources Conservation Service-supplied 2014 QL2 lidar. The 1-meter DEMs from the lidar were hydro-enforced for generating reference streams to help define the upstream limits of the local-resolution National Hydrography Dataset streams. As can be seen from the image below, it is difficult to know where the stream channels are located from the aerial imagery, but the lidar captures the terrain below the tree canopy and all the stream variations. The Geographic Information System software allows analysts to enhance the different topography to see the smallest drainage in otherwise flat areas.

Lidar is also used to identify locations of sand and gravel mining and measure the area of the mining activity. Mines with high-walls (dangerous slopes) are also visible. With only three inspectors for the state, the lidar helps to direct their time appropriately. The color enhanced 1-meter DEM derived from lidar clearly shows digging into the hill and the manmade topographic features as a result of surface sand and gravel mining.

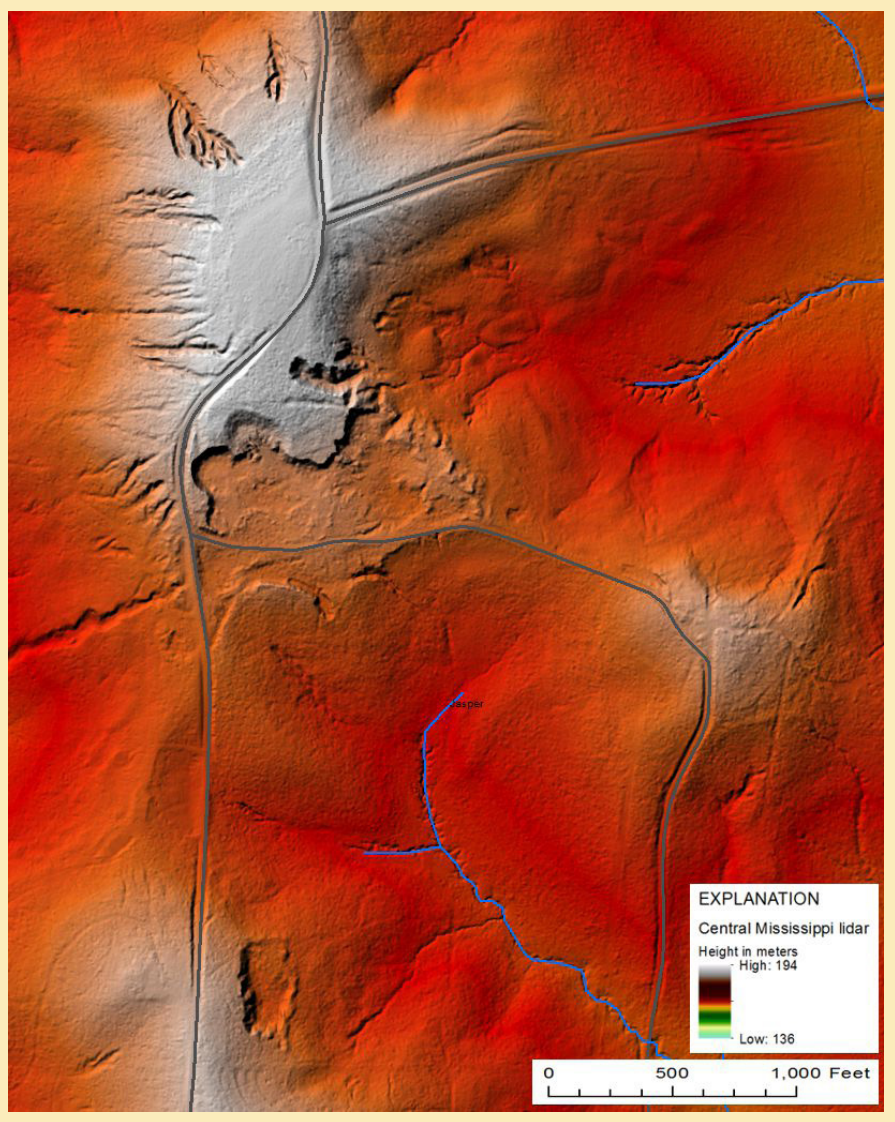

Map showing color enhanced 1-meter digital elevation model derived from light detection and ranging data. The digging into the hillside is most prominently displayed in the mid-left portion of the image. Source: Barbara Yassin, Mississippi Department of Environmental Quality, Office of Geology, Jackson, Mississippi.

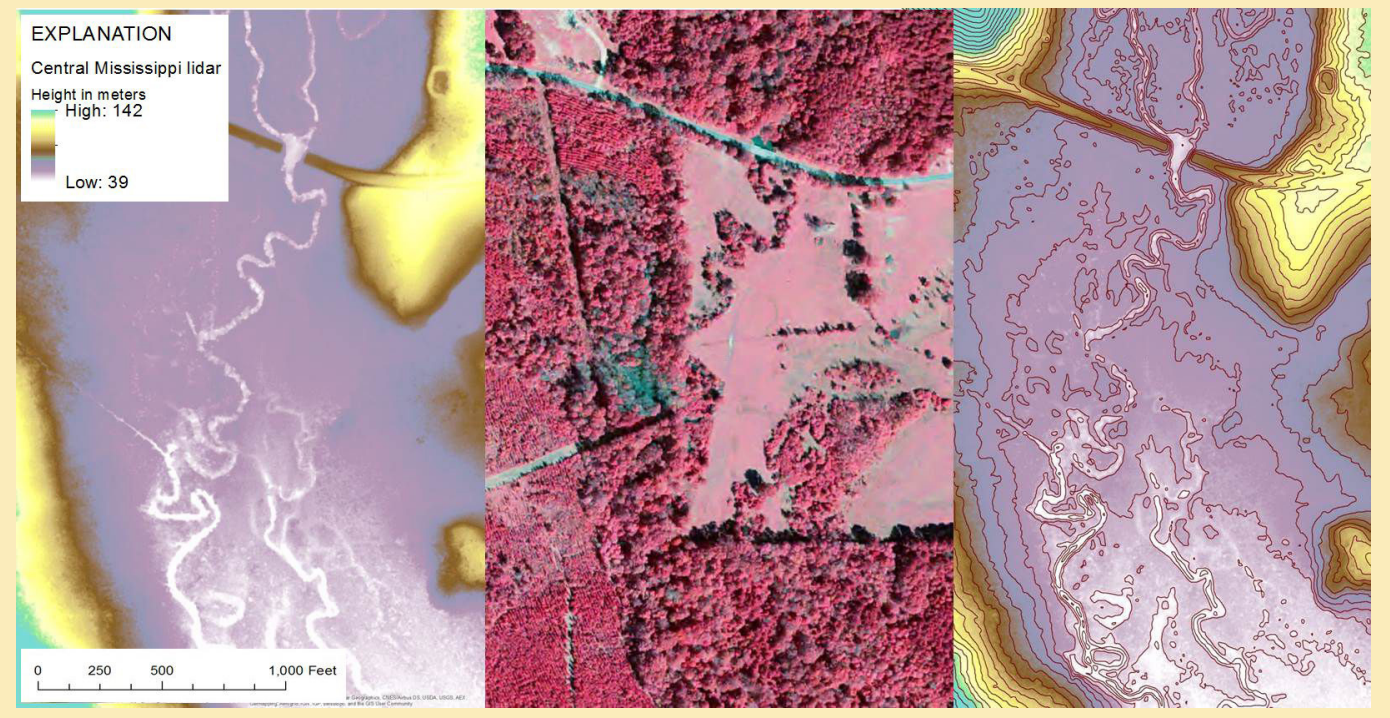

Three images of the same portion of central Mississippi depicted by a high-resolution digital elevation model (DEM) derived from light detection and ranging data (left), aerial imagery (center), and elevation contours displayed over the DEM (right). Source: Barbara Yassin, Mississippi Department. of Environmental Quality, Office of Geology, Jackson, Mississippi. 


\section{D Elevation Program Product Development}

The information technology infrastructure necessary to quality control, manage, and deliver $3 \mathrm{DEP}$ products and services was the primary systems development focus from 2013 to 2015 (Sugarbaker, 2014). The data management and delivery system was built to support lidar point cloud (LPC) projects, IfSAR orthorectified intensity (ORI) images and digital surface models, and standardized digital elevation models (DEMs) at multiple levels of resolution. Additionally, online services to support elevation point query and viewing of elevation surfaces were created. The 3DEP implementation phase also included the transition of all legacy data previously managed under the umbrella of the National Elevation Dataset. Most of this work was completed by early FY15, with the remainder of the year spent accelerating production and improving lidar and IfSAR processing efficiency; for example, once LPC data have been through the QA/QC process, a single workflow catalogs, stores, derives products, and releases data for download to the general public. Although LPC and IfSAR production processing began in FY15, the infrastructure to support higher production rates in FY16 and later years was also being established (fig. 5).

The LPCs and derived products were published for $44,049 \mathrm{mi}^{2}$ in FY15. The projected production in FY16 is $132,500 \mathrm{mi}^{2}$, and in $\mathrm{FY} 17$, production rates are projected to exceed 200,000 $\mathrm{mi}^{2}$ based on the volume of new data collection awards issued in FY14 and FY15. Production statistics are continually being updated. The most current status reports and maps of all USGS published lidar point cloud data are available at http://nationalmap.gov/3DEP/3dep_prodavailability.html.

\section{D Elevation Program Funding}

As shown by the increasing rate of contracting shown in table 1, multiple Federal agencies saw funding increases or allocated greater contributions than in past years to lidar data collection in FY15 (Lukas, 2015). Among Federal, State, local, and Tribal partners, $\$ 46$ million were allocated to acquire data compatible with the 3DEP quality level data, an increase of $\$ 5$ million from FY14. Although the investment levels are increasing, the gap to fully fund 3DEP data collection remains substantial. An additional \$44 million (from all sources) would have been needed for data collection in FY15 to achieve the acquisition rates required for the 8-year program (fig. 6). This analysis was completed using an updated acquisition rate for lidar of $\$ 230$ per square mile. When compared to the original estimate (Dewberry, 2012) of $\$ 277$ per square mile, the total data collection cost estimates are now $\$ 16$ million per year

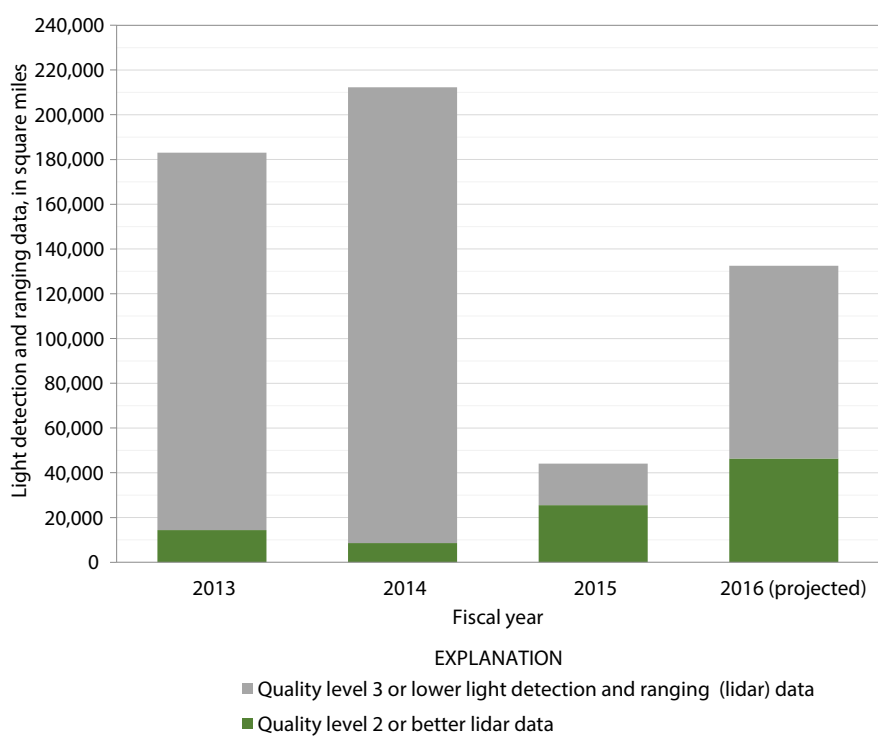

Figure 5. Graph showing new light detection and ranging point cloud data available (2013-15) and projected (2016) for download by fiscal year and quality level.

lower. The analysis also included a revised (small increase) estimate for IfSAR data collection in Alaska. 3DEP operations costs, including contract management, QA/QC, data management, distribution, and administration are not included in the data acquisition gap analysis. Revised operations costs based on a planned program review may be reported at a later date.

The FY15 USGS base budget for 3DEP, including funding for data acquisition and 3DEP related operations (includes data QA/QC, data management, and distribution) was \$20.4 million (U.S. Geological Survey, 2014a). Current estimates are that a USGS base program of $\$ 47$ million is required to meet the financial requirements of an 8-year program. This assumes that the USGS contributes one-third of the total cost share for data acquisition and funds the operational components of 3DEP. The enacted FY16 budget included an increase to the USGS 3DEP of about $\$ 4.3$ million, bringing the base budget to $\$ 24.7$ million (U.S. Geological Survey, 2016a). The President's FY17 budget proposes another increase to the 3DEP base program of about $\$ 5$ million (U.S. Geological Survey, 2016b). These incremental budget increases do help decrease the time to completion of nationwide data coverage; however, at the FY16 funding level, it will take about 14 years to complete nationwide data coverage assuming no repeat acquisition during that period, and a steady rate of acquisition. Various USGS funding scenarios and the time, in years, to complete one cycle of data collection for 3DEP are shown in figure 7. Partner investment increases are also needed to fully address the data acquisition funding gap. Funding need estimates have used the FY15 actual cost based on the analysis presented in table 3. Future costs are assumed to be level. 


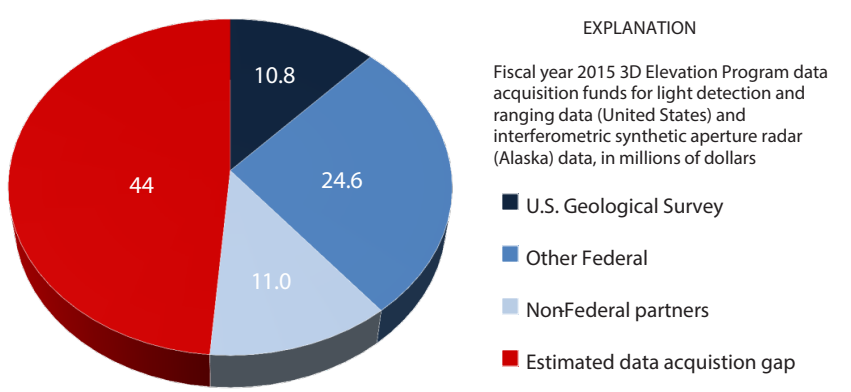

Figure 6. Chart showing fiscal year 2015 3D Elevation Program data acquisition funding and gap to reach annual investment needed for the 8-year program, assuming level investment in each year.

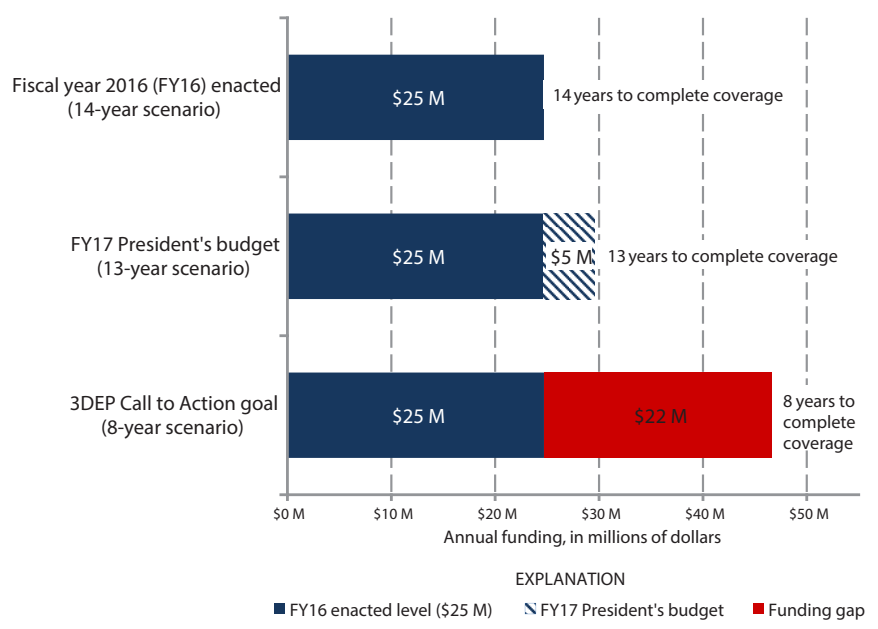

Figure 7. Graph showing U.S. Geological Survey 3D Elevation Program scenarios to fund one-third of data acquisition and to fully fund related quality assurance and quality control, processing, data management, and product delivery.

\section{Community Engagement}

In April 2015, the first 3DEP stakeholder meeting was held in conjunction with the National Surveying, Mapping and Geospatial Conference in Arlington, Virginia. The meeting included representatives from the following organizations:

- 3DEP Executive Forum (represented by the Department of the Interior, Federal Emergency Management Agency, NOAA, Natural Resources Conservation Service, USGS)

- American Society for Photogrammetry and Remote Sensing

- Association of American State Geologists

- Association of State Floodplain Managers

- Coalition of Geospatial Organizations
- Management Association for Private Photogrammetric Surveyors (MAPPS)

- National Geospatial Advisory Committee

- National Society of Professional Surveyors

- National States Geographic Information Council

Participants became more familiar with the planned implementation of 3DEP and helped identify challenges and opportunities for the program. Discussion topics included the need for lidar plans organized at the state government level, 3DEP outreach, tools, and strategies for completing these objectives. The MAPPS proposed to take the lead in uniting stakeholders outside the Federal community in a coalition to communicate about 3DEP, and offered their Web site (http://3DEP4America.com) as a resource. Meeting notes are available online at http://nationalmap.gov/3DEP/ documents/3DEP Stakeholder Meeting NOTES 041515v7.pdf.

The BAA and $3 D E P$ partnership opportunity meetings.The FY15 BAA process included a series of national webinars and public workshops designed to increase awareness and enable stakeholders to prepare in advance for the BAA opportunity. The 39 public workshops held across the country provided an open forum for 3DEP stakeholders to communicate and coordinate potential BAA proposals. The online and in-person workshops held in May and June were attended by 791 participants.

Sky Breaking II.- - In August, the State of Alaska hosted "Sky Breaking II" in Anchorage, Alaska. This event commemorated exceeding the halfway mark for elevation collection of statewide data for Alaska and celebrated the Federal/State collaboration that is making this achievement possible. Numerous dignitaries attended and presented at the event, including Senator Lisa Murkowski, Alaska Governor Bill Walker, U.S. Department of the Interior Principal Deputy Assistant Secretary for Water and Science Jennifer Gimbel, U.S. Geological Survey Director Suzette Kimball, and Alaska Department of Transportation Commissioner Marc Luiken. The Secretary of the Interior, Sally Jewell, spoke through a video that was prepared for the event (Gokey, 2015).

\section{Governance}

3DEP Executive Forum.-The 3DEP Executive Forum facilitates executive dialog and collaboration on strategies to implement and sustain 3DEP for the benefit of its Federal stakeholders and the broader community. The Forum is comprised of representatives from 14 Federal agencies that support 3DEP goals for nationwide data coverage.

The 3DEP Stakeholder Meeting co-hosted by the 3DEP Executive Forum and MAPPS was the highlight of FY15. The Forum also completed the Flood Risk Determination Budget Cross Cut mandated by the Biggert-Waters Legislation (also known as Map21). The Forum coordinated with the Office of Management and Budget to include reporting of Federal 3DEP 
investments in the crosscut, which is reported to Congress. The purpose of the reporting is to track Federal data acquisition investments and highlight coordination towards national goals for data coverage under 3DEP.

3DEP Working Group.-The National Digital Elevation Program (NDEP) was chartered in 2000 as an interagency elevation data coordination group. The NDEP co-sponsored the National Enhanced Elevation Assessment published in 2012 and endorsed the resulting design of 3DEP as a new interagency approach to nationwide elevation data coverage. In FY15, NDEP member agencies developed a new charter to formalize the group as the operational coordination body for the program. The Working Group reports to the 3DEP Executive Forum and supports the newly established 3D Nation Elevation Subcommittee described below. In FY15 the working group focused on publishing Federal data collection requirements as part of the BAA and coordinating data acquisition among the member agencies.

$3 D$ Nation Elevation Subcommittee.-The Federal Geographic Data Committee (FGDC) is organized around National Geospatial Data Asset themes that are coordinated by subcommittees. The Elevation Theme co-leads are the USGS for terrestrial elevation data and NOAA for bathymetric elevation data. The 3D Nation Elevation Subcommittee (fig. 8) was proposed as the formal Elevation Theme subcommittee to the FGDC to serve as a focal point to further coordinate topographic and bathymetric elevation data collection efforts among Federal agencies. The FGDC Steering Committee approved the subcommittee's charter in December 2015. The 3DEP Executive Forum and the 3DEP Working Group steward the acquisition and utilization of terrestrial lidar. The 3DEP Working Group reports to the Executive Forum. The Interagency Working Group on Ocean and Coastal Mapping develops coordinated interagency strategies for the acquisition of bathymetric data; collectively 3DEP and the Interagency Working Group on Ocean and Coastal Mapping develop strategies for terrestrial and bathymetric data in the coastal zones.

Alaska Mapping Executive Committee.-The Alaska Mapping Executive Committee (AMEC) consists of executive managers from multiple Federal agencies and the State of Alaska. These executives meet twice annually to collaborate

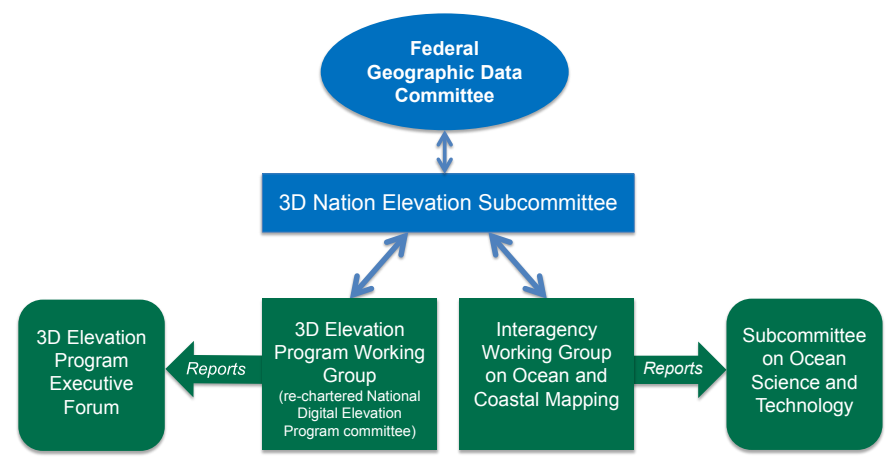

Figure 8. Diagram showing the 3D Elevation Program governance structure.

\section{Light Detection and Ranging Data for Earthquake Hazards Mapping}

\author{
Light detection and ranging (lidar) project-Federal \\ Emergency Management Agency Cache Creek Basin
} Collection year-2015

Quality level $(Q L)$ - QL2, 1-meter digital elevation model State-Oklahoma

Product author-Rob Williams, U.S. Geological Survey

Earthquake Hazards Program

Description - The Cache Creek Basin lidar, acquired by the Federal Emergency Management Agency, has provided highly desirable coverage of the Meers Fault in southwest Oklahoma. Geologists use lidar to examine earthquake faulting in a number of ways. First, for faults that reach and deform the land surface, they use the lidar to map the length and height of the deformed ground surface (scarp). These measurements provide evidence for the size (magnitude) and sense of fault slip (strikeslip, reverse, and so on) of past earthquakes. This kind of science is called tectonic geomorphology. High-resolution lidar can help reveal hidden scarps, especially if they are in wooded areas. A second way they use the lidar is for mapping secondary effects of earthquake ground shaking in the form of liquefaction features, like sand blows. The size of the area covered by sand blows can also provide evidence of earthquake magnitude. This information about the size and type of faulting that comes from these studies can then be incorporated into the U.S. Geological Survey National Seismic Hazard Map.

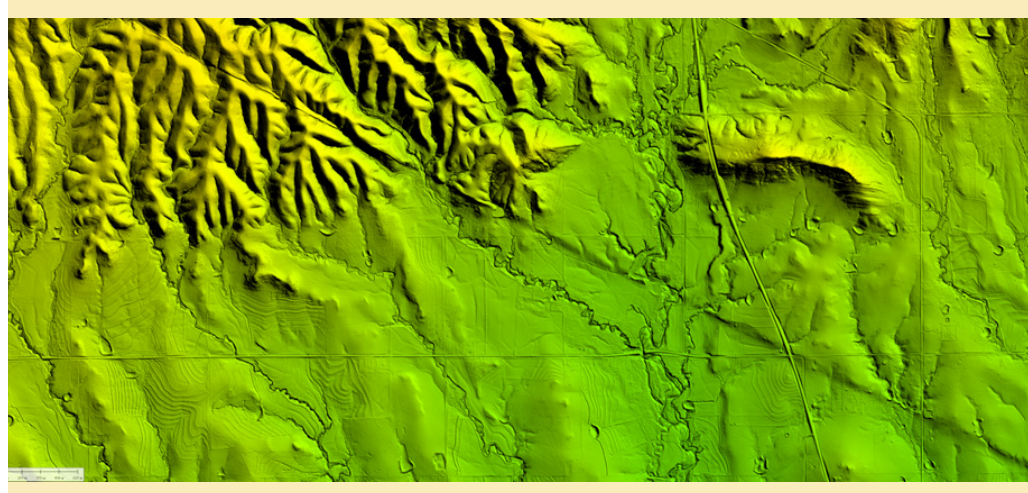

A 1-meter digital elevation model, created from Quality Level 2 light detection and ranging data, depicts part of the Meers Fault in southwest Oklahoma - the only fault east of the Front Range in Colorado with demonstrable Holocene surface displacements. Source: Image was derived from the Federal Emergency Management Agency Cache Creek Basin lidar project. 
and coordinate Alaska statewide mapping activities. AMEC is supported by an Alaska Mapping Technical Subcommittee comprised of mapping professionals from each of the represented agencies. The Technical Subcommittee meets regularly throughout the year to implement program details and develop recommendations when requested by AMEC. On August 20, 2015, AMEC held a special strategic planning meeting in Anchorage. In addition to introducing AMEC activities to many Federal and State managers based in Alaska, the meeting resulted in an 18-month tactical plan focused on accelerating elevation data acquisition in the State and ensuring a smooth transition for the impending changes in Administration.

\section{Advanced Technologies}

The 3DEP is constantly looking for ways to improve efficiencies by investigating and adopting new technologies and methodologies that have the potential to reduce costs while still producing data that satisfies 3DEP requirements. Two new lidar technologies - Geiger-mode (Aull, 2004) and Single-photon counting lidar (Degnan, 2007)_are being evaluated. These instruments have the potential to collect data at higher altitudes than traditional lidar instruments and, as a result, could provide data at a lower cost. The 3DEP is testing the accuracies of these sensors because it has not been conclusively determined if they can meet QL2 or better specifications routinely met by linear mode lidar. Results of the evaluations may be available in the FY16 annual report. Additionally, the Program must assess the full lifecycle costs for processing and managing the data from these sensors before adopting them for use.

Other technologies are beginning to be evaluated as well; for example, topographic-bathymetric lidar has the potential to collect inland bathymetric data under certain conditions related to water clarity, water depth, and other factors. This technology can provide new elevation data for submerged topography where 3DEP has traditionally required hydroflattened water surfaces in DEMs. In addition, structure-frommotion and other image-based photogrammetric processes for deriving $3 \mathrm{D}$ information have the potential to collect data that meet 3DEP accuracy requirements. The use of unmanned aircraft systems as platforms for data acquisition could further affect the utility of these technologies.

\section{Summary}

Fiscal year (FY) 2015 completed the final year of preparation for the $3 \mathrm{D}$ Elevation Program (3DEP) initiative. Fiscal year 2016 is the first year of the 8-year goal to deliver Quality Level 2 light detection and ranging (lidar) data across the conterminous United States, Hawaii, and the U.S. territories and interferometric synthetic aperture radar (IfSAR) data for Alaska. The governance structure is in place with the $3 \mathrm{DEP}$
Executive Forum providing program guidance; the 3DEP Working Group providing interagency coordination and technical advice; and the 3D Nation Elevation Federal Geographic Data Committee Subcommittee providing U.S. Geological Survey (USGS) and National Oceanic and Atmospheric Administration co-leadership for terrestrial and bathymetric data coordination. The Alaska Mapping Executive Committee coordinates the collection of IfSAR data in Alaska.

Data acquisition among all partners for Quality Level 2 lidar continues to increase with 113,896 square miles of new data collected in FY15. Projections for FY16 are that this number will continue to rise. The initial USGS production systems for elevation data products and services and the necessary technology infrastructure are operational. The new systems were used successfully to process and publish more than 44,000 square miles of lidar and derived elevation products in FY15.

The cost of lidar continues to decline, and funding for data acquisition is increasing. The data acquisition funding gap has been reduced to $\$ 44$ million per year, a substantial improvement over previous years. Although the funding challenge has not been fully met, the outlook is very positive as partner agencies, the USGS, and other organizations continue to work toward the 8-year program goal to acquire nationwide coverage of greatly improved elevation data.

\section{References Cited}

American Society for Photogrammetry and Remote Sensing, 2012, LASer (LAS) file format exchange activities: Bethesda, Md., American Society for Photogrammetry and Remote Sensing, accessed August 24, 2015, at http:/www. asprs.org/Committee-General/LASer-LAS-File-FormatExchange-Activities.html.

American Society for Photogrammetry and Remote Sensing, 2014, ASPRS positional accuracy standards for digital geospatial data, edition 1, version 1.0: American Society for Photogrammetry and Remote Sensing, Photogrammetric Engineering and Remote Sensing v. 81, no. 3, p. A1-A26. [Also available at http://dx.doi.org/10.14358/ PERS.81.3.A1-A26.]

Aull, B.F., Loomis, A.H., Young, D.J., Stern, Alvin, Felton, B.J., Daniels, P.J., Landers, D.J., Retherford, Larry, Rathman, D.D., Heinrichs, R.M., Marino, R.M., Fouche, D.G., Albota, M.A., Hatch, R.E., Rowe, G.S., Kocher, D.G., Mooney, J.G., O’Brien, M.E., Player, B.E., Willard, B.C., Zong-Long Liau, and Zayhowski, J.J., 2004, Three-dimensional imaging with arrays of geiger-mode avalanche photodiodes, in Linden, K.J., and Dereniak, E.L, eds., Semiconductor photodetectors: San Jose, Calif., International Society of Optical Engineering, SPIE Proceedings, v. 5353, p. 105-116. [Also available at http://dx.doi. org/10.1117/12.532723.] 
Degnan, J.J.; Wells, David; Machan, Roman; and Leventhal, Edward, 2007, Second generation airborne 3D imaging lidars based on photon counting, in Becker, Wolfgang, ed., Advanced photon counting techniques II: Boston, Mass., International Society of Optical Engineering, SPIE Proceedings, v. 6771. [Also available at http://dx.doi. org/10.1117/12.732086.]

Gokey, Monica, 2015, A project to remap Alaska reaches its halfway point: Alaska Public Media, accessed September 14, 2016, at http:/www.alaskapublic.org/2015/08/18/aproject-to-remap-alaska-reaches-its-halfway-mark/.

Dewberry, 2012, National Enhanced Elevation Assessment final report (rev. March 29, 2012): Fairfax, Va., Dewberry, 84 p. plus appendixes A-J, accessed September 14, 2016, at http://www.dewberry.com/services/geospatial/nationalenhanced-elevation-assessment.

Heidemann, H.K., 2014, Lidar base specification (ver. 1.2, November 2014): U.S. Geological Survey Techniques and Methods, book 11, chap. B4, 67 p. with appendixes, accessed August 24, 2015, at http://dx.doi.org/10.3133/ tm11B4.

Lukas, Vicki, Eldridge, D.F., Jason, A.L., Saghy, D.L., Steigerwald, P.R., Stoker, J.M., Sugarbaker, L.J., and Thunen, D.R. 2015, Status report for the 3D Elevation Program, 2013-2014: U.S. Geological Survey Open-File Report 2015-1161, 17 p., http://dx.doi.org/10.3133/ofr20151161.

Snyder, G.I., Sugarbaker, L.J., Jason, A.L., and Maune, D.F., 2014, National requirements for improved elevation data: U.S. Geological Survey Open-File Report 2013-1237, 371 p., accessed August 24, 2015, http://dx.doi.org/10.3133/ ofr20131237.

Sugarbaker, L.J., Constance, E.W., Heidemann, H.K., Jason, A.L., Lukas, Vicki, Saghy, D.L., and Stoker, J.M., 2014, The 3D Elevation Program initiative-A call for action: U.S. Geological Survey Circular 1399, 35 p., accessed August 24, 2015, at http://dx.doi.org/10.3133/cir1399.

U.S. Geological Survey, 2014a, Budget justifications and performance information-Fiscal year 2015: U.S. Department of the Interior, accessed August 24, 2015, at http://www. usgs.gov/budget/2015/greenbook/2015_greenbook.pdf.

U.S. Geological Survey, 2014b, National Enhanced Elevation Assessment: U.S. Geological Survey, The National Map Web page, accessed August 24, 2015, at http://nationalmap. gov/3DEP/neea.html.

U.S. Geological Survey, 2015a, 3D Elevation Program (3DEP): U.S. Geological Survey, The National Map Web page, accessed 2014 at http://nationalmap.gov/3dep/ BAAReferenceMaterials.html.
U.S. Geological Survey, 2015b, Budget justifications and performance information-Fiscal year 2015: U.S. Department of the Interior, accessed August 24, 2015, at https://www2. usgs.gov/budget/2015/2015index.asp.

U.S. Geological Survey, 2016a, Budget justifications and performance information-Fiscal year 2016: U.S. Department of the Interior, accessed July 25, 2016, at https://www2. usgs.gov/budget/2016/2016index.asp.

U.S. Geological Survey, 2016b, Budget justifications and performance information-Fiscal year 2017: U.S. Department of the Interior, and, accessed July 25, 2016, at https://www. doi.gov/sites/doi.gov/files/uploads/FY2017_USGS_Budget_Justification.pdf. 

For more information concerning this publication, contact: Director, USGS National Geospatial Program

U.S. Geological Survey

12201 Sunrise Valley Drive, MS 511

Reston, VA 20192

Email: 3DEP@usgs.gov 


\section{总}

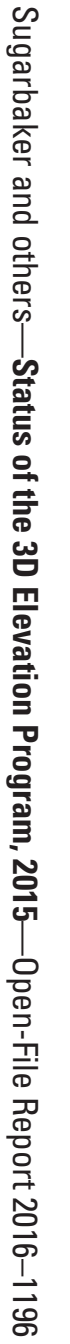

